\title{
Expression
}

\section{John Ruskin's word paintings in the context of his principle of clear vision as well as the biblical and rhetorical tradition}

\author{
Aleksandra Piasecka \\ al.piasecka1@gmail.com
}

\begin{abstract}
This paper focuses on the chosen ekphrases (i.e. literary descriptions of visual works of art) which can be found on the pages of the treatises on painting and architecture written by John Ruskin, one of the most influential Victorian critics. However, these detailed and suggestive passages did not only serve the complementary purpose of illustrating the train of thought of the art connoisseur who was sharing his impressions from the continental tour with the readers. The style of word paintings also owes much to Ruskin's intended lesson in astute observation, regarded as a necessary precondition to understanding the world, and his selfappointed function as a moralist who foresaw the danger of the spiritual decline looming over England. For this reason, first the critic's notions of truth and nature will be discussed to elucidate the importance of clear perception in Ruskin's writings. Then the ekphrases will be analyzed, paying special attention to their language which reveals the roles assumed by the critic. Simultaneously, references to the sources of Ruskin's style, the Bible and ancient rhetoric, will have to be made.
\end{abstract}

Keywords: John Ruskin, Modern Painters, ekphrasis, word painting, nature, rhetoric.

"Ruskin started preaching when he was $22^{1} \ldots "$ - thus M. Niemojowska lightly ironically embarks on her analysis of the ideas expounded in Modern Painters and at the same time aptly describes the prevailing trait of the style adopted by the young critic (Niemojowska 1967, p. 137). The works of the 19th-century English art connoisseur are in fact characterized by a highly rhetorical, authoritative and ornate manner of writing. Moreover, behaving as a genuine preacher, he saw the world as black and white, which resulted in his drawing a sharp

\footnotetext{
${ }^{1}$ My translation.
} 
distinction between the analyzed phenomena and placing them at opposite poles according to the beliefs he subscribed to. Such an unbridgeable gap opens up between two groups of landscape painters: great masters and cunning imitators, the former epitomized by William Turner, and the latter by Nicolas Poussin. This contrasting juxtaposition seems immensely helpful in understanding the role of the attentive eye as a prerequisite for the creation of pictures and literary texts. The aim of the present paper is first to explore Ruskin's notion of clear perception by examining his artistic sympathies and antipathies and then to trace the influence which the concept of acute observation exerted on his descriptions of works of art. Furthermore, the interrelations with the biblical and classical (i.e. rhetorical) tradition will be investigated in order to complete the background to the evocative word paintings of the Victorian critic.

The classification of painters conducted by J. Ruskin was based on his theories of truth to nature, beauty and imagination which provided him with a conceptual framework and a touchstone for evaluating various artists. The abovementioned book, intended to defend $\mathrm{W}$. Turner against the attacks mounted by the critics from "Blackwood Magazine" and "Literary Gazette", bears the full title The Modern Painters: Their Superiority in the Art of Landscape Painting to the Ancient Masters (1843) and its author set himself the aim of presenting W. Turner as a chief exponent of a new school of landscape painting, together with Copley Fielding, James Duffield Harding, James Pyne et al. In an attempt to prove their superiority over the artists of the previous generations, J. Ruskin focused on the advantages of the aforesaid painters. Yet, with the flow of time he extended his knowledge of art and introduced a number of changes in the subsequent edition of Modern Painters (1846) by removing numerous remarks about his contemporaries and discussing the oeuvre of an additional 45 individuals. Some of them came under harsh criticism as those who desperately strove after picturesque qualities in their canvases, "casting all (...) aside to attain those particular truths of tone and chiaroscuro, which may trick the spectator into a belief of reality" (Ruskin 1905a, p. 74).

R. Hewison points out that the accusations leveled at the artists rigidly sticking to the principles of mimesis were of two kinds (Hewison 1976, p. 46-47). First of all, such painters built up a distorted image of nature, concentrating only on her most superficial forms and selecting some of its elements to create a harmonious whole, pleasant to the eye of the beholder. Their vision failed to convey God's ideas hidden behind the visible world, trivializing it and simultaneously manifesting their ignorance about its laws as well as lack of love, which - according to J. Ruskin - constituted a necessary condition for a profound 
understanding of nature. Therefore, he frowned upon their landscapes since they were reflections of the minds which “(...) had neither love of nature, nor feeling of her beauty; (...) [which] looked for her coldest and most commonplace effects, because they were easiest to imitate; and for her most vulgar forms, because they were most easily to be recognized by the untaught eyes of those whom alone they could hope to please" (Ruskin 1905a, p. 75).

Thus, contrary to the widespread assumption that manual dexterity for painting lifelike pictures proves an artist's quality, J. Ruskin perceived keeping absolute fidelity to nature as a sign of taking the easy way out and winning cheap plaudits, tantamount to deliberate deception. This argument was advanced when the critic tried to justify the reasons for the low esteem in which he held Nicolas Poussin, Claude Lorrain and Salvator Rosa, all highly regarded by the public in that time. He put forward an opinion that their self-centeredness resulted in a closed attitude towards nature and inability to lift the veil of its secrets. Consequently, even though they rendered a realistic picture of the world, comparable to photography, it turned out to be false and valueless:“(...) there is one thing wanting in all the doings of these men, and that is the very virtue by which the work of human [original transcription] mind chiefly rises above that of the Daguerreotype or Calotype, or any other mechanical means that ever have been or may be invented, Love: There is no evidence of their ever having gone to nature with any thirst, or received from her such emotion as could make them, even for an instant, lose sight of themselves; there is in them neither earnestness nor humility; there is no simple or honest record of any single truth; none of the plain words nor straight efforts that men speak and make when they once feel” (Ruskin 1905a, p. 77).

Ruskin draws heavily on the example of C. Lorrain who symbolizes for him all the faults of the old school of painting. Even if the critic feels forced to give the painter credit for certain achievements, like being the first to paint sunshine in misty air, it is immediately counterbalanced with a long enumeration of bluntly expressed charges: "His false taste, forced composition, and ignorant rendering of detail have perhaps been of more detriment to art than the gift he gave was of advantage, I know of no other instance of a man's working from nature continually with the desire of being true, and never attaining the power of drawing so much as a bough of a tree rightly" (Ruskin 1905a, p. 89) etc. It proves that notwithstanding his claims to write an impartial treatise, the author of Modern Painters presents highly subjective opinions in his book.

Referring to R. Hewison once again, the second accusation brought against the picturesque painters by J. Ruskin, was their lack of social involvement (Hewison 1976, p. 47). Namely, what inclined them to depict impoverished people was neither compassion nor 
sympathy for the misery of the unfortunate models, but fascination with the possible effects produced by portraying such colourful and intriguing figures. Hence, it was rather their way of dealing with the subject than the choice of topics that the English critic objected to. Nevertheless, there were also artists who achieved vividness in their pictures without falling into the trap of superficiality, by imbuing their works with deep understanding of human dramas. To this group belonged W. Turner.

The painter often touched on the matter of ruins, irreversible flow of time, economic and social deprivation. In this way he managed to reflect in his works a gloomy atmosphere pervading society: the sense of futility of relentless toil and pointlessness of existence together with the awareness of its evanescence. The pessimistic message conveyed by W. Turner finds its expression in the picture depicting the fight between Apollo and Python, a snake which symbolizes sin and corruption. The victory of the god is a misleading one, since another snake is noticeable which comes into being out of the blood of its predecessor. Therefore W. Turner, an artist rendering the beauty of the world but simultaneously aware of evil and suffering lurking behind its visible surface, was called by the author of Modern Painters "Painter of all loveliness of nature, with the worm at its root" (Ruskin 1930, p. 406).

Nonetheless, sensitivity to human suffering was a characteristic stronger emphasized by J. Ruskin at a later stage of his career, when radical social ideas pushed many of his initial interests into the background. As a budding critic, however, he was mostly concerned with the problem of truthfulness to nature. This fidelity did not signify for him an accurate portrayal of the minutest details of reality but a reflection of natural laws observed and comprehended by the artist. He defined truth in art as "the faithful statement, either to the mind or senses, of any fact of nature" (Ruskin 1905a, p. 21). The picturesque artists fell short of this ideal not only due to their lack of knowledge (e.g. Ruskin accuses Claude of incorrect perspective), but also trite preconceptions and cheap tricks which deterred them from the quest for genuineness. Their vision was utterly false, which had far-reaching consequences, since in this way they plunged into confusion and weakened the ties with God: "the truth of nature is a part of the truth of God; to him who does not search it out, darkness, as it is to him who does, infinity" (Ruskin 1905a, p. 50). Though, as R. Hewison notices, the accurate study of fact merely provides a basis for the creative process, whereas it is the way in which the artist uses his observations that occupies the centre of Ruskin's attention (Hewison 1976, p. 65).

To all intents and purposes, the problem of truth is intimately bound up with Ruskin's notion of beauty and its perception. The beautiful, according to the Victorian critic, expresses Divine attributes. It is neither mechanical reception nor an abstract concept but a complex, 
gradual process. Beauty originates from the sensual impression which first stirs up emotions and subsequently awakens love for the perceived object along with the desire for identification with it. Finally, it leads to the discovery of the higher idea behind it, arousing both the feeling of gratitude towards God, as its creator, and the need to worship Him. This process is called "theoria" (i.e. contemplation) by J. Ruskin who, in order to position it in the human mind, coins the term "the theoretic faculty", meaning the link between the eye and the intellect. The theoretic faculty is concerned with the recognition of truth and beauty. Apart from this passive ability, the author of Modern Painters distinguished also an active power, namely the imaginative faculty, required for the recreation of both values.

As far as imagination is concerned, it operates on three separate planes and may be divided accordingly into penetrative, associative and contemplative ones. The penetrative imagination enables the observer to grasp intuitively the external and inner truth of objects and their mutual relations. It is also indispensable to avoid a mistake called by J. Ruskin "a pathetic fallacy" which consists in projecting human emotions onto the inanimate world. The associative imagination, on the other hand, makes it possible for the artist to combine the discerned elements into a new entirety in the chosen medium and in this way share his vision with the others. Finally, the contemplative imagination determines the coming into existence of metaphors and symbols in the artist's mind as it deals with abstract notions which cannot be seen. All three kinds of imagination are activated in the act of perception, which emphasizes how multifaceted and simultaneously crucial to any artistic creation this process is.

Coming back to Ruskin's judgment on artists, the prerequisite of an acute sense of observation and fidelity to nature served him to single out the school of modern landscape painters as opposed to the school of picturesque artists. To the writer's mind, the major distinction was to lie in the honest and open approach to nature of the former:

"[They] have looked at nature with totally different eyes, seeking not for what is easiest to imitate, but for what is most important to tell. Rejecting at once all idea of bona fide imitation, they think only of conveying the impression of nature into the mind of the spectator" (Ruskin 1905a, p. 76).

The painters highly esteemed by J. Ruskin did not resort to deft imitation in an attempt to give a spectacular display of their craft. They possessed a rare gift of astute observation which enabled them to reveal the true nature of the visible world, whereas the intended aim was to conjure up this mental picture on the canvas. In spite of their notable achievements in this field, the artists from the school of modern landscape did not fully attain the ideal. Young 
J. Ruskin, uncritically infatuated with W. Turner, perceived him as the only person who eventually succeeded in it: "Turner is the only painter, so far as I know, who has ever drawn the sky, (...) he is the only painter who has ever drawn a mountain, or a stone (...). He is the only painter who ever drew the stem of a tree (...). He is the only painter who has ever represented the surface of calm, or the force of agitated water; who has represented the effects of space on objects, or who has rendered the abstract beauty of natural color" (Ruskin 1905a, p. 138-139).

Similarly to his lack of moderation in criticism of N. Poussin, J. Ruskin had no limits in praise. It is especially explicit in his controversial vision of W. Turner as a prophet from the Old Testament, the excerpt which illustrates how the impassioned critic was unstoppable once he got on his hobby horse: "[W. Turner is] glorious in conception - unfathomable in knowledge - solitary in power - with the elements waiting upon his will, and the night and the morning obedient to his call, sent as a prophet of God to reveal to men the mysteries of this universe, standing, like the great angel of the Apocalypse, clothed with a cloud, and with a rainbow upon his head, and with the sun and stars given into his hand" (qtd. in Sawyer 1985, p. 48).

The obvious exaggeration of this scene sparked a wave of strong protests from more reserved countrymen. Consequently, J. Ruskin prudently removed this fragment from later editions. The commotion did not, however, disconcert the author who, firstly, was fearless and secondly, had in the meantime found another focus of interest.

J. Ruskin discovered Tintoretto during the journey to Italy in 1845 . Upon seeing the works in the Scuola di San Rocco, the critic enthused about the dash of Tintoretto's painting as well as dynamism and richness of presented forms. This shift in the focus of attention is readily discernible in the second volume of the Modern Painters which - unlike the first one, scarcely mentioning the painter's name - was profuse in references to him. In Ruskin's eyes, Tintoretto was a man endowed with vivid imagination, thanks to which he could imbue paintings with suggestiveness and attach significance even to the most common objects. The issue of imagination became a real subject matter of the book, where the example of the Italian painter helped J. Ruskin to prove his thesis about this faculty as an indispensable condition for any valuable artistic work. It was exceptional imagination that enabled Tintoretto to penetrate the essence of reality and subsequently create, on the basis of collected experiences, a new coherent and beautiful whole.

Tintoretto and W. Turner shared one feature which set them apart from ordinary people - the unique gift of astute perception. J. Ruskin expressed his views on the importance 
of correct observation in the following way: "The greatest thing a human soul ever does in this world is to see something, and tell what it saw in a plain way. Hundreds of people can talk for one who can think, but thousands can think for one who can see. To see clearly is poetry, prophecy, and religion, - all in one" (Ruskin 1905c, p. 333).

Due to the necessity of developing this ability both in order to paint and understand a picture, as well as Ruskin's self-conviction about having possessed the capacity for seeing clearly to a remarkable degree, he assigned himself a task to impart the acquired skill and knowledge to his readers. Thus the abundant descriptions of works of art in Modern Painters fulfilled not only the function of evoking mental images of the masterpieces someone might have not seen, but were also intended to teach him how to approach paintings. One such lesson was given while talking about W. Turner's canvas, The Slave Ship (Ruskin 1905a, p. 382-383).

The painting depicts a tragedy happening at sea when, in face of danger, sailors decide to throw overboard the slaves they are in charge of so as to reduce the weight of the vessel and increase their own chances of survival. J. Ruskin first sketches the general outline of the scene ("It is a sunset on the Atlantic after prolonged storm") and then draws the reader's attention to its successive details: the cloudy sky, the rough sea, and finally, the ship herself. Yet, in no place does he mention drowning people painted in the foreground. If it were not for the footnote ("She is a slaver, throwing her slaves overboard. The near sea is encumbered with corpses"), you would not be aware of the story behind the drama. He creates, however, the atmosphere of imminent threat and grave crime by highlighting the crucial - in his opinion - element, i.e. the colour, and trying to give an illusion of a constant movement via accumulation of verbs. Concentration on the red hue (epithets: "flakes of crimson and scarlet", "purple shadows", "scarlet lines", metaphors "fire of the sunset", "lurid splendor" ) and sharp chiaroscuro ( "glorious light", "like gold", "lamp-like fire", "illumined foam", "flaming flood" are juxtaposed with "hollow of the night", "faint and ghastly shadow", "mist of the night", "dark forms") add to the impression of acute anxiety and mindless violence. Occasional references to blood ("masts written upon the sky in lines of blood", "lurid splendor [...] which bathes like blood") may be read, in the context of the committed atrocity, as an allusion to homicide as well as a harbinger of the doom of the slavers. Moreover, there are a number of phrases which evoke the mood of a lurking danger. They either denote a massive size ("enormous swell", "multitudinous sea") to stress the defenselessness of the human being confronted with the elements (apart from water J. Ruskin often uses the metaphor of fire - "the fire of the sunset", "burns like gold", "lamp-like fire", "burning 
clouds"), or imply indefinable threat (the described shapes are often blurred "indistinguishable images", "mist of the night", "faint and ghastly shadow", "indefinite forms", "like the shadow of death") and growing fear (the adjectives employed to portray nature seem to point to the feelings of fear, loneliness and anger which aroused among the people aboard and in the deep - "fiery path", "[waves] rise [...] fitfully and furiously", "fiery flying", "fearful hue", "fearfully dyed", "desolate heave", "awful [...] light", "treacherous spaces of level").

In addition, the whole scene is a truly dynamic narrative owing to plentiful verbs and verbal adjectives ("falls", "lift", "tossing", "whirling", "moving" to name but a few), the present tense and elaborate sentences. E. Helsinger claims that this energy is not only ascribed to landscape, but also to the intensity of looking and puts forward a thesis that "Painting, like poetry, has become not just the occasion for mental process but also the embodiment of it" (Helsinger 1982, p. 189). In her opinion, the interpretation of the picture's meaning is not always instantaneous and sometimes requires a gradual movement of the eye from one detail to another, which leads first to the discovery of formal relations between them and then also metaphorical senses inscribed in the painter. Such a strategy may be called an "associationist train of ideas" (Wihl 1985, p. 36). J. Ruskin, by directing the reader to the subsequent aspects of The Slave Ship and hinting at their possible connotations, reconstructs the act of looking at the work of art and deciphering its meaning. The main theme of the picture is thus the crime committed by the sailors and the severe punishment which will be inflicted upon them by God for that unforgivable sin. According to R. Stein, there are thus two parallel narratives - "the account of a changing scene and a story of a divine judgment passed against a »guilty« ship" (Stein 1975, p. 15).

Nevertheless, it would be misleading to adhere scrupulously to the traditional symbolism of colours, as G. Wihl notices (Wihl 1985, p. 38-39). He signals some discrepancies between the canvas and its interpretation (temporal disparity) along with inconsistencies within the picture itself: the incongruity between colours, their meaning and the objects they are ascribed to (e.g. sunlight is linked to blood, even though the sun itself is innocent). In his view, the latter was the quality J. Ruskin must have appreciated as a sign of the artist's fidelity to nature, otherwise his work "would suggest falsehood, an artificial manipulation of waves and colours into either a mimetic or an idealized deception" (Wihl 1985, p. 39). The English critic invokes his theory of the artistic truth whilst justifying his high opinion of The Slave Ship ("I believe, if I were reduced to rest Turner's immortality upon any single work, I should choose this") and asserts that the whole conception "is based on the 
purest truth", which together with "the concentrated knowledge of a life" gives a profound and valuable depiction of the scene, giving the spectator the impression of "the power, majesty, and deathfulness of the open, deep, illimitable Sea" (Ruskin 1905a, p.383). This conclusion makes it clear why the passage on the W. Turners work was incorporated in the chapter Of Truth of Water (Ruskin 1905a). According to R. Stein, though, the issue of fidelity to nature in Ruskin's writings was inextricably bound up with the problem of imagination even at an early stage of the critic's career when his conception of it had not yet been fully developed (Stein 1975, p. 12). Hence, it would not be too far-fetched, R. Stein maintains, to say that great imagination was the feature admired by J. Ruskin equally to the painter's acute sense of observation: "Turner's »nobility« depends on his mastery of natural phenomena; his art translates physical »facts« into harmonious expressions of his imagination" (Stein 1975, p.12). However, it was in the second volume of Modern Painters when J. Ruskin started to delve exhaustively into the subject of imagination. The successor of W. Turner in the author's hierarchy, Tintoretto, was a notable exponent of an artist particularly endowed with this gift.

The extraordinary imagination of the painter comes to the fore in the text on the picture entitled The Massacre of the Innocents (Ruskin 1905b, p. 179-181). J. Ruskin builds the composition of the passage on a series of contrasts. First, he mentions the failed renderings of this biblical topic by those who tried to come to grips with their task by representing emotions too sophisticated, whereas in the stark reality of a mortal danger the feelings become reduced to the simplest and most intense ones: fear and rage. Not until then does J. Ruskin juxtapose the efforts of the mistaken painters with the outcome of Tintoretto's work:

“(...) the ordinary representations of this subject are, I think, false and cold: the artist has not heard the shrieks, nor mingled with the fugitives, he has sat down in his study to twist features methodically, and philosophize over insanity. Not so Tintoret [original transcription] Knowing or feeling, that the expression of the human face was in such circumstances not to be rendered, and that the effort could only end in an ugly falsehood he denies himself all aid from the features, he feels that if he is to place himself or us in the midst of that maddened multitude, there can be no time allowed for watching expression" (Ruskin 1905b, p. 180).

Therefore, the difference between Tintoretto and the rest lies in his honesty not to take a short cut and depict the feelings he has not observed and can only clumsily try to envisage. Instead, what J. Ruskin appreciates, Tintoretto runs the risk of ignoring the facial expression and conveys the extreme emotions by the use of chiaroscuro (called by the author of Modern Painters "an awful substitute of [murder and ghastliness of death]") and adding dynamism to 
the scene. As in the example discussed above, J. Ruskin reflects the tumult and confusion dominating the picture by a number of verbs denoting rapid movements (to hurl, drag, dash, crush...) and the fact that the descriptive part almost solely consists of one tremendously long sentence, formed by replacing full stops with semicolons.

It is not blind panic, however, that J. Ruskin finds the most appealing to the spectator. In the final fragment comparable to the climax of the description, he suddenly slows down the frantic pace, and focuses on the solitary figure in the background, frozen in unbearable suffering over the dead body of her baby: "It is a woman, sitting quiet, - quite quiet - still as any stone, she looks down steadfastly on her dead child, laid along on the floor before her, and her hand is pressed softly upon her brow" (Ruskin 1905b, p. 181). The repetition of synonymous phrases ("quiet", "quite quiet", "still as any stone") brings about gradation of the intensity of silence and lack of movement, which stands in the marked contrast to the rest of the picture. As the slaughter has not yet been stopped, quietness reigns obviously only in the mind of the bereaved mother who is shocked by her loss. This figure and her pain epitomize for J. Ruskin the highest expression of despair conceived in the mind of Tintoretto owing to his fertile imagination.

According to G. Landow, such a noble expression of feelings was to be, in the eyes of the Victorian critic, a meeting point of painting and literature (Landow 1968, p. 523). In the third volume of Modern Painters J. Ruskin emphasizes the interconnection between the two arts saying that he uses "the words painter and poet quite indifferently" (Ruskin 1905c, p. 221). The passage on Tintoretto's painting illustrates his attempt not only at conveying emotions but also a struggle for a vivid language. To the techniques he applies belong, apart from frequent and often symbolic epithets (like "sanguine shadows"), comparisons. Some of them are Homeric ones, e.g. "a lake of life before them, like the burning seen of the doomed Moabite on the water that came by the way of Edom". On the one hand, the figure highlights the pervasive sense of dread, whereas the fall of Moabites prefigures the imminent death of children. On the other hand, it is one of numerous references to the Bible present throughout the pages of Ruskin's works. He occasionally cites entire sentences overtly putting quotation marks (e.g. "I am the door; by me if any man enters in, he shall be saved" [Ruskin 1905d, p. 112] ), but in many cases simply relies on the reader's vigilance and sufficient familiarity with the foundations of the Christian faith both in spotting and recognizing his allusions as well as finding out the reason for making them ("a desert place, where the foxes have holes and the birds of the air have nests" (Ruskin 1905b, p. 174). Sometimes the whole context allows drawing a parallel between the object in question and a given phenomenon of a 
biblical provenance (Wheeler's reading of St. Mark's in Venice as the Byzantine version Solomon's temple (Wheeler 1999, p. 31); or Rosenberg's gambling people under the figure of Christ before the basilica as dicing soldiers under the cross (Rosenberg 1986, p. 92). The protestant upbringing of the critic, with its Sunday ritual of reading the Bible in the family circle, provided him with an extensive knowledge of its contents, a constant reference point for his theories as well as a mine of proverbs, quotations and comparisons.

J. Ruskin drew his inspiration not only from the Christian heritage. Equally important to him was the classical tradition, especially rhetoric, which is closely connected with the fact that the practice of describing visual works of art has its origin in antiquity. For vivid verbal representations of paintings or buildings, the Greek coined the phrase ekphrasis (Latin descriptio), stemming from the verb "ekphrazein" which means "to show very clearly, to make completely clear" (Clüver 1998, p. 36-37). Such portrayals served initially as exercises for future orators but over the course of time became a genre on its own (eg Imagines by Philostratus the Elder) or parts of a larger whole. The primary function that the ekphrastic text has to perform, known by the name enargeia, consists in creating a visual image in the mind of the listener and in such a way turning him into a spectator (Scholz 1998, p. 81).

Therefore, it may seem surprising at first that although literary descriptions of works of art were anything but new to the Victorian public, Ruskin's vivid style came in for scathing criticism. The young author was compared to a "whirling Dervish who at the end of his wellsustained reel falls with a higher jump and a shriller shriek into a fit" by "Athenaeum" (Bradley 1995, p. 67), whereas "Blackwood Magazine" admitted frankly: "The picture, if it be painted by the graduate, must be a curiosity - we can make neither head nor tail of his words" (Bradley 1995, p. 48). The reason for this stir lies in the fact that the English were accustomed to a markedly different approach to paintings. Throughout the eighteenth and at the beginning of the nineteenth century, writers like W. Hazlitt used to look at visual works of art from the angle of literature, focusing chiefly on the depicted story. It was due to the widespread belief that there is a clear hierarchy of the arts and literature assumes a preeminent position in relation to painting, so any comparison between them results in enhancing the status of the latter. Its lower rank was inferred from manual labor needed for the execution of pictures whereas writing poems was regarded as a purely mental work. Moreover, for Romantic critics literature directly embodied an imaginative process while painting could only stimulate a train of associated ideas (Helsinger 1982, p. 183). Contrary to earlier evocations of images, Ruskin's ekphrases, by concentrating on the picture itself and not on the narrative behind it, undermine the privileged status of literature and reflect his conviction 
that painting also allows tracing the mental process of its creator. The very minuteness of the critic's descriptions, which threw his contemporaries into considerable confusion, adhered to the principles of enargeia more closely that his predecessors' sketchiness.

As a consequence of having their roots in orations, ekphrastic texts strongly stress the presence of the reader. A closer look at Ruskin's debt to the rhetorical assumptions will be taken on the basis of his description of St. Mark's in Venice. The narration of the Stones of Venice is led in a manner that strongly emphasizes the company of another person, less versed in the complexities of Italian art than the speaker. J. Ruskin, who may be identified as the speaker, addresses the listener directly ("Then look farther to the south" [Ruskin 1905d, p. 12] ), asks questions (“And what effect has this splendor on those who pass beneath it?" [Ruskin 1905d, p. 68] ) and uses the first person plural to tell what route is just being taken or what detail admired ("We will push fast through them into the shadow of the pillars" [Ruskin 1905d, p. 66] ). By doing so, he evokes in the reader the feeling of participation in the tour and adopts the role of a guide. This position explains his frequent exertion of authority by showing a full control over the joint undertaking ("I shall not, except when it is absolutely necessary, direct attention to the discordant points, or weary the reader with anatomical criticism" [Ruskin 1905d, p. 63] ). The guide does not refrain from bossing his charge about ("If, therefore, the reader does not care for color, I must protest against his endeavor to form any judgment whatever of this church of St. Mark's") but his arbitrariness seems to be justified by the desire to enrapture the reader with the beauty of the basilica and to make him understand it better. As in the speech, J. Ruskin utters exclamations ("Between that grim cathedral of England and this, what an interval!" [Ruskin 1905d, p.68] ) and interlards the narration with digressions ("I shall pursue this subject farther in another place; but I allude to it here in order to ..." [Ruskin 1905d, p.108] ). Yet, he is simultaneously careful not to lose the thread and confuse the reader, thus the announcements introducing the order often appear in the text ("Here I must pass on to the second part of our immediate subject ...We have here evidently two questions:..." [Ruskin 1905d, p. 97] ); (or "I shall, in a future portion of this work, endeavor to discover what probabilities there are of our being able to use this kind of art in modern churches; but at present it remains for us to ...” [Ruskin 1905d, p. 111] ). Thanks to these strategies the guide seems to be a person, on the one hand, competent and resolute, but on the other, attentive to the reader.

Additionally, Ruskin's work reveals other similarities to oration. J. Ziomek reminds that Cicero set apart three aims of a speech: to convince (docere), to bring pleasure (delectare) and to move (flectere) (Ziomek 1990, p. 57-58). All three may be found in The 
Stones of Venice. The abovementioned attempts to avoid ambiguity serve to win the reader's approval. The pleasure is achieved via ornate language, hence Ruskin's ekphrasis abounds in metaphors (e.g. "a marble foam" [Ruskin 1905d, p. 68] ), similes (the sculptures of angels "like the morning light as it faded back among the branches of Eden, when first its gates were angel-guarded long ago" [Ruskin 1905d, p. 67] ), periphrases (the basilica - "a treasure-heap" [Ruskin 1905d, p. 67] ), and syntactical parallelisms ("clear as amber and delicate as ivory" [Ruskin 1905d, p. 67] ). Finally, the reader is moved thanks to stronger tropes and figures: hyperboles ("a multitude of pillars", [Ruskin 1905d, p. 67] ), enumerations ("sculpture ... of palm leaves and lilies, and grapes and pomegranates, and birds clinging and fluttering among the branches" [Ruskin 1905d, p.67] ), contrasts (the sacred of the church and the profane of the surrounding street), antithetical juxtapositions ("Priest and layman, soldier and civilian, rich and poor" [Ruskin 1905d, p. 68] ). Therefore, J. Ruskin sticks to the principles of the classical oration in order to impress the reader and only then does he attempt to deploy his arguments concerning the interpretation of St. Mark's. This aim was defined by the author in the last lines of the chapter on the basilica: "And this thought may surely dispose the reader to look with some change of temper upon the gorgeous building and wild blazonry of that shrine of St. Mark's. He now perceives that it was in the hearts of the old Venetian people far more than a place of worship. It was at once a type of the Redeemed Church of God, and a scroll for the written word of God. It was to be to them, both an image of the Bride, all glorious within, her clothing of wrought gold; and the actual Table of the Law and the Testimony, written within and without" (Ruskin 1905d, p. 115-116).

Consequently, J. Ruskin regards the richly decorated church as a sermon on the articles of faith. Observing among Venetians a growing indifference towards the building that corresponds to their attitude to religion, he strives after stimulating interest for its works of art and deepening their understanding. In this way, J. Ruskin hopes to enable disorientated people to regain faith.

Such a sublime purpose required appropriate language, according to the ancient rule of decorum. Thus, apart from the strategies and figures of speech discussed above, J. Ruskin uses numerous biblical references: i.a. he compares the basilica to "the star of the Magi" (Ruskin 1905d, p. 117), quotes passages from the New Testament ("He shall return, to do judgment and justice" [Ruskin 1905d, p.116] ) and makes allusions ("Up to the very recesses of the porches, the meanest tradesmen of the city push their counters; nay, the foundations of its pillars are themselves the seats - not »of them that sell doves« for sacrifice, but of the 
vendors of toys and caricatures" refers to the Christ's expulsion of merchants from the temple [Ruskin 1905d, p. 68] ). It imbues his utterances with the sense of loftiness and solemnity.

Ruskin's grandeur of style points toward the role he has assumed - the one of a preacher, whose task is to convert stray sheep. Still, it is just one of the guises the critic takes on. E. Helsinger discerns three of them: J. Ruskin as an amateur, an expert and an artist's spokesman (Helsinger 1982, p. 13-19). The first mask, she claims, serves to stress the significance of visual experience as a source of knowledge, playing down the substance of erudition. It may be epitomized by the pseudonym "a Graduate of Oxford", under which the first volume of Modern Painters was published. Its author poses as an educated gentleman (so not a professional art critic) distinguished by the skill of acute observation and willing to share it with anyone showing inclination to learn it. The second guise, on the other hand, accentuates the moral authority of the scholar and thus corresponds to the already discussed function of a preacher. The last attitude of J. Ruskin is that of a translator of the painter's pictorial speech into a verbal language. It subsists in providing methods for the analysis of works of art along with their descriptions. As a result, a pronounced shift from the passionate enthusiasm of an amateur to the high seriousness of a sage may be observed in Ruskin's books.

In spite of using such a polymorphous style, the Victorian critic - according to G. Landow - remained consistent in this sense that throughout his career he wrote invariably as an exegete (Landow 1985, p. 6-7, 15-16). The act of seeing and interpreting constitutes, in the eyes of the author of Modern Painters, a decisive step towards understanding different areas of human experience. In consequence, he tries to encourage readers to observe the world by furnishing them with his word paintings, intended to convey the received impressions, together with the possible readings of the perceived phenomena.

In conclusion, the English critic's elaborate style of ekphrases is not accidental. On the contrary, it results from his understanding of the adopted roles - of an enthusiastic art connoisseur, a preacher addressing his contemporaries and a painter's spokesman. All these functions aim at convincing the audience and thus justify his drawing on the rhetorical tradition. Besides, the worthy cause J. Ruskin fought for, i.e. the revival of genuine religious faith among his countrymen and prevention from moral decline, led to his use of biblical language as appropriately impressive and solemn. Combining these two fertile sources of inspiration, the critic worked out his own peculiar style: on the one hand appealing to the reader, and on the other, overwhelming him to the point of being incapable of refuting the presented arguments. Yet, the ability to notice the growing problems of 19th-century England 
was inextricable from the wider issue of acute perception of reality. Thus, J. Ruskin demonstrated his own strategy of observing the world in numerous ekphrases, both of natural phenomena and works of art, which imparted unusual suggestiveness to his writings.

\section{Sources}

Ruskin J. (1905a), [in:] Cook E. T., Wedderburn A. (eds.), The Complete Works of John Ruskin: Modern Painters I, Vol. 3., Allen, London; Longmans, Green and Co, New York.

Ruskin J. (1905b), [in:] Cook E. T., Wedderburn A. (eds.), The Complete Works of John Ruskin: Modern Painters II,. Vol. 4., Allen, London; Longmans, Green and Co, New York. Ruskin J. (1905c), [in:] Cook E. T., Wedderburn A. (eds.), The Complete Works of John Ruskin: Modern Painters III, Vol. 5., Allen, London; Longmans, Green and Co, New York. Ruskin J. (1905d), [in:] Cook E. T., Wedderburn A. (eds.), The Complete Works of John Ruskin: The Stones of Venice II, Vol. 10, Allen, London; Longmans, Green and Co, New York.

Ruskin J. (1930), Modern Painters V, Merill and Baker, New York.

\section{Bibliography}

Bradley J.L. (1995) (ed.), The Critical Heritage. 2nd ed. Routledge, London.

Brooks M.W. (1987), John Ruskin and Victorian Architecture, Rutgers UP, New Brunswick.

Clüver C. (1998), Quotation, Enargeia, and the Functions of Ekphrasis, [in:] Clüver C.,

Robbilard V. (eds), Pictures into words: theoretical and descriptive approaches to ekphrasis, VU UP, Amsterdam.

Clüver C., Robbilard V. (eds), Pictures into words: theoretical and descriptive approaches to ekphrasis, VU UP, Amsterdam.

Helsinger E. (1982), Ruskin and the Art of the Beholder, Mass: Harvard UP, Cambridge. Hewison R. (1976), John Ruskin: The Argument of the Eye, Thames and Hudson, London. Kemp W. (1991), The Desire of My Eyes: The Life and Work of John Ruskin, van Heurck J. (trans.), HarperCollins, London.

Landow G.P. (1968) Ruskin's Version of "Ut Pictura Poesis”, "Journal of Aesthetics and Art Criticism" 26.

Niemojowska M. (1976), Zapisy zmierzchu. Symboliści angielscy i ich romantyczny rodowód, Czytelnik, Warszawa. 
Rosenberg J.D. (1986), The Darkening Glass: A Portrait of Ruskin's Genius, Columbia UP, New York.

Sawyer P.L. (1985), Ruskin's Poetic Argument: The Design of the Major Works, Cornell UP, Ithaka.

Scholz B.F. (1998), "Sub Oculos Subiektio”: Quintilian on Ekphrasis and Enargeia, [in:]

Robillard V., Scholz B.F. (eds.), Pictures into words: theoretical and descriptive approaches

to ekphrasis, VU UP, Amsterdam.

Stein R. L. (1975), The Ritual of Interpretation. The Fine Arts as Literature in Ruskin,

Rossetti, and Pater, Harvard UP, Cambridge.

Wihl G. (1985), Ruskin and the Rhetoric Infallibility, Yale UP, New York.

Wheeler M. (1999), Ruskin's God, Cambridge UP, Cambridge.

Ziomek J.(1990), Retoryka opisowa, Ossolineum, Wrocław.

\section{Netography}

Landow G.P. (1985), Ruskin, Oxford: Oxford UP, http://www.victorianweb.org/authors/ruskin/pm/contents.html, retrieved: 9.12.2006; 26.11.2010.

\section{Ruskin's description of The Slave Ship by W. Turner}

"But, I think, the noblest sea that Turner has ever painted, and, if so, the noblest certainly ever painted by man, is that of the Slave Ship, the chief Academy picture of the Exhibition of 1840. It is a sunset on the Atlantic after prolonged storm; but the storm is partially lulled, and the torn and streaming rain-clouds are moving in scarlet lines to lose themselves in the hollow of the night. The whole surface of sea included in the picture is divided into two ridges of enormous swell, not high, nor local, but a low, broad heaving of the whole ocean, like the lifting of its bosom by deep-drawn breath after the torture of the storm. Between these two ridges, the fire of the sunset falls along the trough of the sea, dyeing it with an awful but glorious light, the intense and lurid splendor which burns like gold and bathes like blood. Along this fiery path and valley, the tossing waves by which the swell of the sea is restlessly divided, lift themselves in dark, indefinite, fantastic forms, each casting a faint and ghastly shadow behind it along the illumined foam. They do not rise everywhere, but three or four together in wild groups, fitfully and furiously, as the under strength of the swell compels or permits them; leaving between them treacherous spaces of level and whirling water, now lighted with green and lamp - like fire, now flashing back the gold of the 
declining sun, now fearfully dyed from above with the indistinguishable images of the burning clouds, which fall upon them in flakes of crimson and scarlet, and give to the reckless waves the added motion of their own fiery flying. Purple and blue, the lurid shadows of the hollow breakers are cast upon the mist of the night, which gathers cold and low, advancing like the shadow of death upon the guilty ${ }^{\left[{ }^{*}\right]}$ ship as it labors amidst the lightning of the sea, its thin masts written upon the sky in lines of blood, girded with condemnation in that fearful hue which signs the sky with horror, and mixes its flaming flood with the sunlight, - and cast far along the desolate heave of the sepulchral waves, incarnadines the multitudinous sea.

I believe, if I were reduced to rest Turner's immortality upon any single work, I should choose this. Its daring conception - ideal in the highest sense of the word - is based on the purest truth, and wrought out with the concentrated knowledge of a life; its color is absolutely perfect, not one false or morbid hue in any part or line, and so modulated that every square inch of canvas is a perfect composition; its drawing as accurate as fearless; the ship buoyant, bending, and full of motion; its tones as true as they are wonderful; and the whole picture dedicated to the most sublime of subjects and impressions - (completing thus the perfect system of all truth, which we have shown to be formed by Turner's works) - the power, majesty, and deathfulness of the open, deep, illimitable Sea”.

[*] She is a slaver, throwing her slaves overboard. The near sea is encumbered with corpses.

(MP I: 382-383)

\section{Ruskin's description of The Massacre of Innocents by Tintoretto}

"I have before alluded, Sect. I. Chap. XIV., to the painfulness of Raffaelle's treatment of the massacre of the innocents. Fuseli affirms of it that, »in dramatic gradation he disclosed all the mother through every image of pity and of terror«. If this be so, I think the philosophical spirit has prevailed over the imaginative. The imagination never errs, it sees all that is, and all the relations and bearings of it, but it would not have confused the mortal frenzy of maternal terror with various development of maternal character. Fear, rage, and agony, at their utmost pitch, sweep away all character: humanity itself would be lost in maternity, the woman would become the mere personification of animal fury or fear. For this reason all the ordinary representations of this subject are, I think, false and cold: the artist has not heard the shrieks, nor mingled with the fugitives, he has sat down in his study to twist features methodically, and philosophize over insanity. Not so Tintoret. Knowing or feeling, that the expression of the human face was in such circumstances not to be rendered, and that 
the effort could only end in an ugly falsehood, he denies himself all aid from the features, he feels that if he is to place himself or us in the midst of that maddened multitude, there can be no time allowed for watching expression. Still less does he depend on details of murder or ghastliness of death; there is no blood, no stabbing or cutting, but there is an awful substitute for these in the chiaroscuro. The scene is the outer vestibule of a palace, the slippery marble floor is fearfully barred across by sanguine shadows, so that our eyes seem to become bloodshot and strained with strange horror and deadly vision; a lake of life before them, like the burning seen of the doomed Moabite on the water that came by the way of Edom; a huge flight of stairs, without parapet, descends on the left; down this rush a crowd of women mixed with the murderers; the child in the arms of one has been seized by the limbs, she hurls herself over the edge, and falls head down most, dragging the child out of the grasp by her weight; she will be dashed dead in a second: two others are farther in flight, they reach the edge of a deep river, - the water is beat into a hollow by the force of their plunge; - close to us is the great struggle, a heap of the mothers entangled in one mortal writhe with each other and the swords, one of the murderers dashed down and crushed beneath them, the sword of another caught by the blade and dragged at by a woman's naked hand; the youngest and fairest of the women, her child just torn away from a death grasp and clasped to her breast with the grip of a steel vice, falls backwards helplessly over the heap, right on the sword points; all knit together and hurled down in one hopeless, frenzied, furious abandonment of body and soul in the effort to save. Their shrieks ring in our ears till the marble seems rending around us, but far back, at the bottom of the stairs, there is something in the shadow like a heap of clothes. It is a woman, sitting quiet, - quite quiet - still as any stone, she looks down steadfastly on her dead child, laid along on the floor before her, and her hand is pressed softly upon her brow".

(MP II: 180-181)

\section{Ruskin's description of St. Mark's in Venice}

„We will push fast through them into the shadow of the pillars at the end of the »Bocca di Piazza«, and then we forget them all; for between those pillars there opens a great light, and, in the midst of it, as we advance slowly, the vast tower of St. Mark seems to lift itself visibly forth from the level field of chequered stones; and, on each side, the countless arches prolong themselves into ranged symmetry, as if the rugged and irregular houses that pressed together above us in the dark alley had been struck back into sudden obedience and lovely order, and all their rude casements and broken walls had been transformed into arches charged with goodly sculpture, and fluted shafts of delicate stone. 
And well may they fall back, for beyond those troops of ordered arches there rises a vision out of the earth, and all the great square seems to have opened from it in a kind of awe, that we may see it far away; - a multitude of pillars and white domes, clustered into a long low pyramid of colored light; a treasure-heap, it seems, partly of gold, and partly of opal and mother-of-pearl, hollowed beneath into five great vaulted porches, ceiled with fair mosaic, and beset with sculpture of alabaster, clear as amber and delicate as ivory, - sculpture fantastic and involved, of palm leaves and lilies, and grapes and pomegranates, and birds clinging and fluttering among the branches, all twined together into an endless network of buds and plumes; and, in the midst of it, the solemn forms of angels, sceptred, and robed to the feet, and leaning to each other across the gates, their figures indistinct among the gleaming of the golden ground through the leaves beside them, interrupted and dim, like the morning light as it faded back among the branches of Eden, when first its gates were angelguarded long ago. And round the walls of the porches there are set pillars of variegated stones, jasper and porphyry, and deep-green serpentine spotted with flakes of snow, and marbles, that half refuse and half yield to the sunshine, Cleopatra-like, »their bluest veins to kiss « - the shadow, as it steals back from them, revealing line after line of azure undulation, as a receding tide leaves the waved sand; their capitals rich with interwoven tracery, rooted knots of herbage, and drifting leaves of acanthus and vine, and mystical signs, all beginning and ending in the Cross; and above them, in the broad archivolts, a continuous chain of language and of life - angels, and the signs of heaven, and the labors of men, each in its appointed season upon the earth; and above these, another range of glittering pinnacles, mixed with white arches edged with scarlet flowers, - a confusion of delight, amidst which the breasts of the Greek horses are seen blazing in their breadth of golden strength, and the St. Mark's Lion, lifted on a blue field covered with stars, until at last, as if in ecstasy, the crests of the arches break into a marble foam, and toss themselves far into the blue sky in flashes and wreaths of sculptured spray, as if the breakers on the Lido shore had been frost-bound before they fell, and the sea-nymphs had inlaid them with coral and amethyst".

(SoV II: 67-68) 